Vol 5 No 1 Maret 2018

\title{
Kekuatan Hukum Sertifikat Hak Tanggungan Dalam Hal Musnahnya Obyek Hak Tanggungan Karena Bencana Alam Di Kabupaten Grobogan
}

\author{
Ariel Doni Dharmawan*, Maryanto**
}

* Mahasiswa Program Magister
arieldoni1102@gmail.com

** Dosen Fakultas Hukum UNISSULA \section{)}

\begin{abstract}
ABSTRAK
Kekuatan Hukum Sertifikat Hak Tanggungan dalam hal musnahnya objek Hak Tanggungan karena bencana alam di Kabupaten Grobogan menjadi menarik untuk dibahas penulis, karena menimbulkan dampak bagi pihak kreditur. Dimana kreditur kehilangan objek atau benda jaminan yang sedang dibebani hak tanggungan. Dalam hal ini debitur tidak dapat disalahkan karena musnahnya objek atau benda yang dibebani hak tanggungan musnah oleh bencana alam, karena kapan terjadi dan dimana terjadinya bencana tidak dapat diduga dan diluar kekuasaan para pihak, hal ini merupakan keadaan memaksa atau overmacht/ forje majeur. Sehingga penulis merumuskan beberapa permasalahan, yang pertama adalah bagaimana kekuatan hukum sertifikat hak tanggungan dalam hal musnahnya objek hak tanggungan karena bencana alam, lalu permasalahan yang kedua adalah bagaimana perlindungan hukum terhadap pemegang sertifikat hak tanggungan yang musnah karena bencana alam.

Pada penulisan tesis ini, penulis menggunakan metode pendekatan yang digunakan dalam penelitian ini adalah metode yuridis sosiologis (socio legal research) yang berarti mengidentifikasi suatu persoalan hukum dari sudut pandang sosial. Untuk menjawab permasalahan seputar hukum perdata terkait tentang Hak Tanggungan. Hasil penelitian yang dilakukan oleh penulis, pertama didapatkan bahwa kekuatan sertifikat hak tanggungan hapus apabila objek hak tanggungan telah musnah oleh bencana alam walaupun hal ini merupakan keadaan yang tidak disengaja dan di luar kekuasaan para pihak. Permasalahan kedua bahwa perlindungan hukum terhadap pemegang hak tanggungan, di dapatkan melalui prosedur pemberian kredit oleh pihak kreditur/ pemegang hak tanggungan, dengan melaksanakan prinsip kehati-hatian sehingga pihak kreditur dapat memperkecil resiko debitur cidera janji/ lalai/ wanprestasi. Adanya formulir syarat umum yang diberi stempel Notaris atau PPAT dibaca dan apabila disetujui oleh debitur, tanda tangan diatas materai. Kemudian, adanya prosedur penerbitan akta hak tanggungan baik itu SKMHT maupun APHT hingga pendaftaran sertifikat hak tanggungan di BPN hal ini untuk mendapatkan kekuatan hukum secara otentik dan mutlak sehingga apabila terjadi sesuatu dapat ditangani berdasarkan dasar hukum dan ketentuan yang telah disetujui oleh para pihak.
\end{abstract}

Kata kunci :Sertifikat Hak Tanggungan, Objek Hak Tanggungan, Bencana Alam

\begin{abstract}
The Legal Strength of the Certificate of Mortgage Right in the event of the disappearance of the object of Mortality Right due to natural disaster in Grobogan district becomes interesting to be discussed by the author, because it has an impact for the creditor. Where a creditor loses an object or collateral item that is being burdened with a mortgage. in this case the debtor can'tbe blamed for the disappearance of objects or objects burdened by the mortgage is destroyed by natural disasters, because when and where the occurrence of disasters can't be expected and beyond the power of the parties, this is a state of coercion or overmacht / forjemajeur. So the authors formulate some problems, the first is how the legal power of dependent certificates in the event of loss of mortgage objects due to natural disasters, then the second problem is how the legal protection of the dependent certificate holder who destroyed by natural disasters.

In writing this thesis, the author uses the approach method used in this study is sociological juridical method (socio legal research) which means identifying a legal issue from a social point of view. which is a scientific research that has a function to answer the problems surrounding civil law. In the results, the first problem can be concluded that the strength of the mortgage certificate is deleted if the object of mortgage rights has been destroyed by natural disasters even though this is an unintentional situation and outside the power of the parties. In second case, it can be concluded that the legal protection of the mortgage holders is obtained through credit lending procedure by the creditor / holder of mortgage, by implementing the prudential principle so that the creditor can minimize the risk of the default / negligent debtor. The existence of a general terms form to be
\end{abstract}


readed, and stamped by Notary or PPAT and signature by the debtor. Then, the procedure of SKMHT or APHT until registration of certificate of mortgage right in BPN.

Keywords: Certificate of Mortgage Right, Object of Mortgage Rights, Natural Disaster

\section{PENDAHULUAN}

Setiap orang membutuhkan tempat untuk tinggal untuk berlindung, berteduh, menetap dalam suatu tempat, namun kebutuhan manusia akan tempat tinggal sekarang ini semakin sulit dipenuhi karena berbagai faktor, salah satunya biaya yang tidak murah untuk membeli lahan/ tanah, mendirikan/ membangun tempat tinggal (rumah), lahan yang semakin terbatas. Di sisi lain apabila masyarakat sudah dapat membeli lahan/tanah yang diinginkan, maka pemegang hak atas tanah perlu memberikan perlindungan dan kepastian hukum terhadap lahan/tanah yang telah dibeli, dengan cara pengurusan Sertifikat tanah Hak Milik (SHM) sebagai bukti lahan/tanah tersebut sudah dimiliki secara sah.

Sertifikat Hak atas tanah diperlukan sebagai bukti kuat dan sah bagi pemegang hak, pada saat yang sama, hak atas tanah yang diwujudkan dalam bentuk Sertifikat tanah juga memberikan kekuatan hukum dan kewenangan kepada pemegang hak untuk memakai suatu bidang lahan/tanah yang bertujuan untuk memenuhi kebutuhan tertentu. Baik digunakan untuk pertanian, perkebunan, peternakan, perikanan, bangunan gedung, jalan, taman, bahkan pekarangan untuk membangun rumah sebagai tempat tinggal. Untuk menjamin kepastian hukum hak atas tanah, dilaksanakan Pendaftaran Tanah. Pemegang hak atas tanah diberikan kewenangan untuk menggunakan, memungut hasil dari tanah tersebut. Pemegang hak atas tanah juga diberikan kewenangan untuk mempergunakan tubuh bumi, air, dan ruang yang ada diatasnya untuk kepentingan yang langsung berhubungan dengan penggunaan tanah tersebut. Selain itu, salah satu hak atas tanah yang dibuktikan dengan kepemilikan Sertifikat oleh pemegang hak, adalah menjaminkan hak atas tanah, jaminan dapat berupa surat-surat berharga, atau sertifikat tanah kepada pihak bank dengan tujuan pengambilan dana tambahan atau pembiayaan tertentu, dengan cara dibebani Hak Tanggungan. ${ }^{1}$ Tentunya apabila pemegang hak atas tanah/ pemohon ingin menjaminkan tanahnya untuk mendapatkan pinjaman dari bank, maka sertifikat

\footnotetext{
${ }^{1}$ Urip Santoso, Pendaftaran dan Peralihan Hak Atas Tanah, Edisi Pertama, Cetakan ke-1, Kencana Prenada Media Group, Jakarta, 2010, HIm. 408
}

merupakan syarat paling penting selain identitas pemegang hak/ pemohon. Pihak bank dalam membebankan hak tanggungan pada pemohon perlu melihat identitas dan sertifikat yang diajukan sebagai jaminan lolos atau tidak.

Debitur, selama menerima fasilitas kredit, bukti kepemilikan tanah yang berupa sertifikat hak atas tanah akan dibebankan hak tanggungan. Dalam hal ini yang menjadi permasalahan, apabila obyek jaminan hak tanggungan tersebut lenyap, akibat peristiwa alam/ bencana alam yang mengakibatkan tanah yang dijaminkan musnah seperti tanah longsor, banjir bandang ataupun gempa, hal ini menimbulkan permasalahan. Tentunya sertifikat tanah yang dijaminkan, yang kemudian diterbitkan Sertifikat Hak Tanggungan menjadi tidak jelas kedudukannya, karena obyek yang tertera penjelasan rincinya di dalam sertifikat telah musnah. Permasalahan ini menimbulkan akibat hukum. Tentang musnahnya obyek tanah yang dibebani hak tanggungan tidak diatur dalam Undang-undang Pokok Agraria maupun dalam Undang-Undang Hak Tanggungan. Hal ini menjadi permasalahan tersendiri, dimana kedudukan sertifikat Hak Tanggungan menjadi tidak jelas secara hukum, padahal Sertifikat Hak Tanggungan mempunyai kekuatan hukum eksekutorial dan menjadi bukti kuat bagi pemegang Hak Tanggungan.

Kekuatan Sertifikat Hak Tanggungan secara hukum menjadi sulit untuk dibuktikan, karena bukti fisik yang telah musnah. Selain itu timbul permasalahan lain, yaitu perlindungan hukum bagi pemegang sertifikat Hak Tanggungan dimana obyek yang dibebani Hak Tanggungan telah musnah. Bagi pemegang sertifikat Hak Tanggungan akan sulit mendapatkan perlindungan, karena hal ini belum diatur dalam Undang-Undang Hak Tanggungan, sehingga menimbulkan kekosongan peraturan. Tentunya ini sangat vital, karena peraturan hukum yang menjadi dasar dan landasan pelaksanaan, dalam hal ini perlindungan bagi pemegang Sertifikat Hak Tanggungan yang obyeknya musnah karena bencana alam belum ada. Bagi pemegang Sertifikat Hak Tanggungan, apabila hal ini terjadi akan merugikan. Oleh karena itu, seperti yang sudah dijelaskan di atas, bahwa Sertifikat Hak Tanggungan jelas memiliki kekuatan eksekutorial dan menjadi 
bukti yang kuat. Apabila obyek hak tanggungan musnah karena bencana alam, menjadi permasalahan serius. Berdasarkan uraian tersebut, maka penulis tertarik untuk mengangkat dan meneliti permasalahan ini dengan memilih judul "Kekuatan Hukum Sertifikat Hak Tanggungan Dalam Hal Musnahnya Obyek Hak Tanggungan Karena Bencana Alam "

\section{Metode Penelitian}

Mengadakan suatu penelitian ilmiah jelas harus menggunakan metode. Metode berarti penyelidikan yang berlangsung menurut suatu rencana tertentu. Menempuh suatu jalan tertentu untuk mencapai tujuan, artinya peneliti tidak bekerja secara acak-acakan. Langkah-langkah yang harus diambil harus jelas serta ada pembatasanpembatasan tertentu untuk menghindari jalan yang menyesatkan dan tidak terkendalikan. ${ }^{2}$

Penelitian yang dilakukan penulis menggunakan metode yang dengan cara menguraikan data secara bermutu dalam bentuk kalimat yang teratur, runtut, logis, tidak tumpang tindih, dan efektif, sehingga memudahkan pemahaman dan interpretasi data $^{3}$. Metode pendekatan yang digunakan dalam penelitian ini adalah metode yuridis sosiologis (sociolegal research) yang berarti mengidentifikasi suatu persoalan hukum dari sudut pandang sosial ${ }^{4}$. Penulis menggunakan metode pendekatan yuridis sosiologis, yang merupakan penelitian ilmiah yang memiliki fungsi untuk menjawab permasalahan seputar hukum perdata terkait tentang Hak Tanggungan, yang bertujuan untuk melihat kesesuaian hukum dengan keadaan sebenarnya di lapangan ${ }^{5}$.

\section{HASIL PENELITIAN DAN PEMBAHASAN}

\section{Kekuatan Hukum Sertifikat Hak Tanggungan dalam hal Musnahnya Objek Hak Tanggungan karena Bencana Alam.}

Berdasarkan hasil wawancara dengan salah satu warga yang bertempat tinggal di Desa Kunden Kecamatan Wirosari, terdapat kasus yang terjadi di

\footnotetext{
2 Johhny Ibrahim, Teori dan Metodologi Penelitian Hukum Normatif, Bayumedia Publishing, Surabaya, 2011, HIm. 294

${ }^{3}$ Abdukadir Muhammad, Hukum dan Penelitian Hukum, Citra Aditya Bakti, Bandung, 2004, HIm. 172

${ }^{4}$ Bahder Johan Nasution, Metode Penelitian Hukum, Mandar Maju, Bandung, 2008, HIm. 129-130

${ }^{5}$ Ronny Hanitijo Soemitro, Metodologi Penelitian Hukum dan Jurimetri, Ghalia Indonesia, Jakarta, 1998, HIm. 22
}

daerah Desa Kunden, Kecamatan Wirosari, Kabupaten Grobogan, Provinsi Jawa Tengah, antara Salah satu bank pemerintah (BUMN) ${ }^{6}$ yaitu Bank Rakyat Indonesia Kantor Cabang Pembantu Wirosari, sebagai pemegang Hak Tanggungan dengan salah satu nasabah/debiturnya sebagai penerima Hak Tanggungan. Penerima Hak Tanggungan menjaminkan tanah beserta bangunan diatasnya sebagai objek Hak Tanggungan. Proses dari pengajuan kredit, prosedur pemberian kredit, kemudian prosedur diterbitkannya Akta Pembebanan Hak Tanggungan hingga pendaftaran dan diterbitkannya Sertifikat Hak Tanggungan oleh Badan Pertanahan Nasional (BPN) semua berjalan lancar dan sesuai prosedur. Pada suatu waktu ada kejadian yang menyebabkan objek yg dibebankan hak tanggungan menjadi musnah, baik tanah dan bangunan diatasnya, dikarenakan terkena musibah tanah longsor. Musibah tanah longsor yang terjadi menyebabkan seluruh bangunan dan tanah yang dijadikan objek Hak Tanggungan menjadi musnah, disisi lain pinjaman yang diberikan kreditur sebagai pemegang Hak Tanggungan belum lunas. ${ }^{7}$ Hal ini membuat rancu, mengenai Sertifikat Hak Tanggungan yang sudah terbit apakah masih berlaku dan bagaimana kekuatan hukum Sertifikat Hak Tanggungan tersebut.

Musnahnya objek hak tanggungan sangat berdampak pada kekuatan hukum sertifikat hak tanggungan, hal ini dikarenakan objek (tanah) yang diikat oleh hak tanggungan telah musnah. Kekuatan hukum sertifikat hak tanggungan dapat dilihat dari keabsahan sertifikat hak tanggungan itu sendiri, dimana sah atau tidaknya sebuah sertifikat hak tanggungan dapat dilihat dari terpenuhinya syaratsyarat dan prosedur pemberian hak tanggungan yang secara jelas sudah diatur dalam UndangUndang Hak Tanggungan pemberian hak tanggungan, dimana disebutkan dalam Bab IV tentang Tata Cara Pemberian, Pendaftaran, Peralihan, dan Hapusnya Hak Tanggungan Pasal 10, 11, 12, 13, dan Pasal 15.

a. Proses Pemberian Hak Tanggungan

Tata cara penetapan pemberian hak tanggungan dalam Undang-Undang Hak Tanggungan dibedakan menjadi 2 (dua) yaitu yang

\footnotetext{
${ }^{6}$ BUMN singkatan dari Badan Usaha Milik Negara

${ }^{7}$ Hasil wawancara, pihak warga penerima hak tanggungan (debitur) asal Desa Kunden, Kecamatan Wirosari, Pada tanggal 4 Oktober 2017
} 
pertama pemberian hak tanggungan melalui SKMHT yang dilanjutkan dengan APHT dan yang kedua melalui APHT. Penjelasan Pasal 15 ayat (1) UndangUndang Hak Tanggungan SKMHT digunakan dalam hal pemberi hak tanggungan tidak dapat hadir dihadapan PPAT, diperkenankan penggunaan SKMHT. Sejalan dengan itu, surat kuasa tersebut harus diberikan langsung oleh pemberi hak tanggungan dan harus memenuhi persyaratan. Untuk hak atas tanah yang sudah terdaftar, wajib diikuti dengan pembuatan APHT selambat-lambatnya 1 (satu) bulan sesudah diberikan, sedangkan terhadap hak atas tanah yang belum terdaftar harus dipenuhi dalam waktu 3 (tiga) bulan. ${ }^{8}$ Alasan lain penggunaan SKMHT adalah sertifikat hak atas tanah yang akan menjadi jaminan belum melalui proses cheking pada kantor Badan Pertanahan Nasional setempat. Sehingga tidak bisa dilakukan pengikatan dengan APHT langsung. Pemberian hak tanggungan yang didasarkan oleh SKMHT diatur dalam Pasal 15 Undang-Undang Hak Tanggungan. SKMHT merupakan kuasa untuk membebankan hak tanggungan ini meliputi kuasa untuk menghadap pejabat (dalam hal ini Notaris atau PPAT dan pejabat di Kantor Badan Pertanahan Nasional) untuk memberikan keterangan-keterangan yang diperlukan dalam proses pemberian dan pendaftaran hak tanggungan, serta memperlihatkan dan menyerahkan surat-surat yang diminta, membuat/minta dibuatkan serta menandatangani APHT serta suratsurat lain yang diperlukan. Dalam SKMHT pemberi kuasa memberi pernyataan bahwa obyek hak tanggungan benar milik pemberi kuasa, tidak tersangkut dalam sengketa, bebas dari sitaan dan dari beban-beban apapun. Selain itu dalam SKMHT juga mencantumkan janji-janji dari pemberi kuasa (debitur atau penjamin) dan dari penerima kuasa (kreditur). Kuasa yang diberikan dengan SKMHT ini tidak dapat ditarik kembali oleh pemberi kuasa dan tidak berakhir karena sebab apapun kecuali telah dilaksanakan pembuatan APHT. Pemberian hak tanggungan dengan APHT diatur dalam Pasal 10 Undang-Undang Hak Tanggungan.

Undang-Undang Hak Tanggungan menentukan isi yang sifatnya wajib untuk sahnya APHT. Ketentuan mengenai isi APHT tersebut yang sifatnya wajib bagi sahnya pemberian hak tanggungan yang bersangkutan. Jika tidak dicantumkan secara lengkap maka APHT yang bersangkutan batal demi

\footnotetext{
${ }^{8}$ Adrian Sutedi,Op.cit,HIm. 62
}

hukum. ${ }^{9}$ Substansi dari APHT diatur dalam Pasal 11 Undang-Undang Hak Tanggungan Pendaftaran APHT dirumuskan dalam Pasal 13 hingga Pasal 14 UndangUndang Hak Tanggungan. Setelah APHT dibuat oleh PPAT dan kemudian ditandatangani oleh para pihak, kemudian APHT tersebut bersama warkah dan sertifikat tanda bukti hak atas tanah didaftarkan di kantor pertanahan setempat. Tidak dilakukannya pencatatan akan mengakibatkan tidak berlakunya perbuatan hukum yang dikehendaki oleh para pihak terhadap pihak ketiga. Pihak ketiga boleh percaya pada publikasi yang telah dilakukan, pencatatan dalam publikasi tidak dapat dipergunakan untuk merugikan hak dan kepentingan pihak ketiga yang beritikad baik. ${ }^{10} \mathrm{Hak}$ tersebut berarti publikasi dan pencatatan diabaikan, maka para pihak tidak dapat mendalilkan hubungan yang ada diantara para pihak terhadap pihak ketiga. Berdasarkan pemaparan diatas maka dapat disampaikan pemberian hak tanggungan dapat dilakukan melalui dua cara yaitu pemberian hak tanggungan dengan SKMHT yang kemudian dilanjutkan dengan APHT, dan yang kedua dengan APHT. APHT tersebut bersama warkah dan sertifikat tanda bukti hak atas tanah didaftarkan di kantor pertanahan setempat paling lambat 7 (tujuh hari) setelah ditandatangani. Badan Pertanahan Nasional membuat buku tanah hak tanggungan dan mencatatnya dalam buku tanah hak atas tanah yang menjadi obyek hak tanggungan serta menyalin catatan tersebut pada sertifikat hak atas tanah yang bersangkutan. Kemudian dikeluarkan sertifikat hak tanggungan dan sertifikat hak atas tanah yang sudah dibebani hak tanggungan.

Apabila sudah memenuhi syarat-syarat dan melalui prosedur dari ketentuan - ketentuan dalam Pasal diatas. Sertifikat Hak Tanggungan memiliki kekuatan hukum yang tetap dan eksekutorial dan sah. Dalam hal ini, Undang-Undang Hak Tanggungan belum mengatur kedudukan sertifikat hak tanggungan yang obyeknya musnah karena bencana alam. Kondisi ini merupakan kekosongan norma dalam Undang-Undang Hak Tanggungan. Kekosongan norma tersebut menimbulkan ketidakpastian hukum atas peristiwa musnahnya seluruh obyek hak tanggungan yang diakibatkan oleh bencana alam.

\section{b. Hapusnya Hak Tanggungan}

\footnotetext{
${ }^{9}$ Boedi Harsono, Op.cit, HIm. 441

${ }^{10}$ Kartini Muljadi dan Gunawan Widjaja, Kebendaan Pada Umumnya, Prenada Media, Jakarta, 2003, HIm. 67
} 
Berdasarkan pemaparan diatas maka dapat disampaikan bahwa berdasarkan ketentuan Pasal 27, Pasal 34, dan Pasal 40 Undang-Undang Pokok Agraria yang mengatur tentang hapusnya hak milik, hak guna usaha, dan hak guna bangunan salah satunya disebabkan oleh faktor yang sama yaitu musnahnya tanah tersebut. Hal ini menjelaskan bahwa di dalam KUH Perdata maupun UUPA hak atas tanah dapat hapus apabila tanah tersebut musnah. Salah satunya karena terkena bencana alam yang mengakibatkan tanah tersebut musnah. Namun dalam Undang-Undang Nomor 4 Tahun 1996 tentang Hak Tanggungan Atas Tanah Beserta Benda-Benda Yang Berkaitan Dengan Tanah yang selanjutnya disebut UUHT tidak menyebutkan secara rinci atau tidak ada klausula yang menyebutkan bahwa hapusnya hak atas tanah salah satunya dikarenakan tanahnya musnah.

Berakhirnya hak tanggungan tertuang dalam ketentuan Pasal 18 ayat (1) UUHT, yang menyatakan bahwa hak tanggungan berakhir atau hapus karena beberapa hal sebagai berikut:

(1) Hak Tanggungan hapus karena hal-hal sebagai berikut;

a. Hapusnya hutang yang dijamin dengan Hak Tanggungan

b. Dilepaskannya Hak Tanggungan oleh Pemegang Hak Tanggungan

c. Pembersihan Hak Tanggungan berdasarkan penetapan peringkat oleh Ketua Pengadilan Negeri.

d. Hapusnya hak atas tanah yang dibebani Hak Tanggungan

Hal ini menjadi menarik, dimana UUHT sebagai dasar hukum dalam melakukan pembebanan Hak Tanggungan baik melalui SKMHT ${ }^{11}$ maupun $\mathrm{APHT}^{12}$ terhadap objek yang dijaminkan oleh debitur, tidak secara rinci menyebutkan mengenai akibat musnahnya tanah objek hak tanggungan terhadap sertifikat hak tanggungan. Berdasar ketentuan Pasal 18 ayat (1) huruf d UUHT ini, secara mendalam dapat diartikan bahwa Undang-Undang Hak Tanggungan merumuskan salah satu faktor yang dapat menghapuskan hak tanggungan adalah hapusnya hak atas tanah yang dibebani hak tanggungan, jadi musnahnya seluruh tanah yang menjadi obyek hak tanggungan karena suatu peristiwa diluar keinginan debitur dan kreditur yaitu

\footnotetext{
${ }^{11}$ Surat Kuasa Membebankan Hak Tanggungan

${ }^{12}$ Akta Pembebanan Hak Tanggungan
}

bencana alam akan mengakibatkan hapusnya/ tidak berlakunya sertifikat hak tanggungan atas obyek tersebut atau kembali lagi melihat ketentuan di dalam KUH Perdata dan UUPA dimana alasan-alasan hapusnya hak atas tanah disebutkan dengan sangat jelas. Alasan hapusnya hak tanggungan yang disebabkan karena hapusnya hak atas tanah yang dibebani hak tanggungan tidak lain dan tidak bukan adalah sebagai akibat tidak terpenuhinya syarat objektif sahnya perjanjian khususnya yang berhubungan dengan kewajiban adanya objek tertentu, yang salah satunya meliputi keberadaan dari sebidang tanah tertentu yang dijaminkan. Dengan demikian, berarti setiap pemberian hak tanggungan harus memperhatikan dengan cermat hal-hal yang dapat menyebabkan hapusnya hak atas tanah yang dibebankan dengan hak tanggungan. Oleh karena itu, setiap hal yang menyebabkan hapusnya hak atas tanah tersebut demi hukum juga akan menghapuskan hak tanggungan yang dibebankan diatasnya, meskipun bidang tanah dimana hak atas tanahnya tersebut hapus tetapi masih tetap ada, dan selanjutnya telah diberikan pula hak atas tanah yang baru atau yang sama jenisnya. Dalam hal yang demikian, maka kecuali kepemilikan hak atas tanah telah berganti, maka perlu dibuatkan lagi perjanjian pemberian hak tanggungan yang baru, agar hak kreditor untuk memperoleh pelunasan dapat dipertahankan. Hak atas tanah dapat hapus antara lain karena hal-hal sebagaimana disebut dalam Pasal 27, Pasal 34 dan Pasal 40 UndangUndang Nomor 5 Tahun 1960 tentang KetentuanKetentuan Pokok Agraria atau Peraturan Perundangundangan lainnya yang mengatur pula tentang halhal yang mengakibatkan hapusnya hak atas tanah. Dalam hal Hak Guna Usaha, Hak Guna Bangunan atau Hak Pakai yang dijadikan objek hak tanggungan berakhir jangka waktu berlakunya dan diperpanjang berdasarkan permohonan yang diajukan sebelum berakhirnya jangka waktu tersebut, hak tanggungan dimaksud tetap melekat pada hak atas tanah yang bersangkutan.

Hapusnya Hak Tanggungan karena longsor membawa dampak administratif, yaitu menghapus beban hak tanggungan pada buku tanah dan sertifikat hak atas tanah yang menjadi objek hak tanggungan oleh Kantor Pertanahan setempat berdasarkan surat pernyataan tertulis mengenai dilepaskannya hak tanggungan dari pemegang hak tanggungan kepada pemberi hak tanggungan 
sehubungan dengan pelunasan utangnya oleh debitur. ${ }^{13}$

Menurut Pasal 22 UUHT setelah hak tanggungan dihapus, Kantor Pertanahan mencoret catatan hak tanggungan tersebut pada bukti tanah hak atas tanah dan sertifikatnya. Adapun sertifikat hak tanggungan yang bersangkutan ditarik dan bersama-sama buku hak tanggungan dinyatakan tidak berlaku lagi oleh Kantor Pertanahan. ${ }^{14}$ Pencoretan karena ada roya ${ }^{15}$ dilakukan dengan mencatat hapusnya hak tanggungan yang bersangkutan yaitu pada buku tanah dan serttifikat hak tanggungan yang bersangkutan ${ }^{16}$

Dalam musnahnya objek hak tanggungan memiliki konsekuensi bagi kedua belah pihak, bagi pemegang hak tanggungan/ kreditur maupun bagi penerima hak tanggungan/ debitur, walaupun tanah yang dibebani hak tanggungan musnah karena terkena bencana alam, yang terjadi di luar kekuasaan atau kekuatan dari kreditur maupun debitur itu sendiri yang kemudian menimbulkan keadaan memaksa atau yang disebut overmacht atau dapat juga disebut force majeur.

Konsekuensinya terhadap debitur, dimana sudah dijelaskan diatas bahwa walaupun tanah yang dijaminkan telah musnah karena bencana alam, debitur tetap harus melunasi kewajibannya terhadap kreditur hingga selesai. Kondisi ini tidak menguntungkan debitur karena, selain masih harus melunasi kewajibannya, tanahnya yang dibebani hak tanggungan pun telah musnah. Hapusnya hak tanggungan tidak mengakibatkan hilangnya kewajiban debitur untuk melunasi kewajibanya kepada kreditur. Kewajiban tersebut harus tetap diselesaikan sesuai dengan perjanjian kredit yang menjadi dasar lahirnya hak tanggungan. Selain itu, kondisi tidak menguntungkan pun juga dialami oleh kreditur selaku pemegang hak tanggungan. Dimana kreditur telah melaksanakan kewajibannya kepada debitur, tetapi kreditur telah kehilangan objek yang dijadikan jaminan untuk dibebankan hak tanggungan, begitu juga mengenai status dari kreditur tersebut. Dimana pada saat lahirnya hak

\footnotetext{
${ }^{13}$ Mohammad Machfudh Zarqoni, Hak Atas Tanah Perolehan, Asal Dan Turunannya, Serta Kaitannya Dengan Jaminan Kepastian Hukum (Legal Guarantee) Maupun Perlindungan Hak Kepemilikannya (Property Right), Prestasi Pustaka Publisher, Jakarta, 2015, HIm.57

${ }^{14}$ Ibid, HIm. 57

${ }^{15}$ Roya, adalah Pencoretan catatan

${ }^{16}$ Pasal 2 ayat (2) Undang-undang Hak Tanggungan jo Pasal 16 Undang-undang Nomor 16 Tahun 1985
}

tanggungan, status dari kreditor adalah kreditur preference atau yang diutamakan, tetapi karena musnahnya objek hak tanggungan yang mengakibatkan hapusnya sertifikat hak tanggungan statusnya berubah menjadi kreditor konkuren, sehingga kreditor tidak memiliki hak jaminan yang kuat dan kepastian hukum akan dilunasinya hutang debitur, Hapusnya hak tanggungan ini akan menimbulkan ketidakpastian hukum bagi bank selaku kreditur, atas ketidakpastian ini maka diperlukan pelindungan hukum bagi kreditur. Untuk menyelesaikan masalah keabsahan sertifikat hak tanggungan yang obyeknya musnah karena bencana alam, maka digunakan metode kontruksi argumentum per analogiam (analogi) ${ }^{17}$. Analogi yang digunakan adalah menganalogikan sertifikat hak tanggungan sebagai sebagai suatu perjanjian. Syarat sahnya suatu perjanjian telah diatur dalam Pasal 1320 KUH Perdata. Pasal 1320 KUH Perdata merumuskan:

Untuk sahnya persetujuan-persetujuan itu diperlukan empat syarat:

a. Sepakat mereka yang mengikatkan dirinya;

b. Cakap untuk membuat suatu perikatan;

c. Suatu hal tertentu;

d. Suatu sebab yang halal.

Keempat syarat tersebut mutlak diperlukan agar suatu perjanjian tersebut sah. Apabila suatu perjanjian tidak memenuhi syarat kesepakatan dan kecakapan maka perjanjian tersebut dapat dibatalkan sedangkan apabila perjanjian tersebut tidak memenuhi syarat suatu hal tertentu dan klausa yang halal maka perjanjian tersebut batal demi hukum. Berdasarkan syarat-syarat perjanjian maka salah satu unsur perjanjian yaitu suatu hal tertentu (obyek) perjanjian yaitu tanah telah musnah diakibatkan oleh suatu peristiwa bencana alam sehingga termasuk suatu keadaan overmacht. Tanpa obyek yang jelas, perjanjian sulit atau bahkan mustahil dilakukan oleh para pihak. Perjanjian yang tidak jelas obyeknya bukanlah perjanjian yang sah sehingga batal demi hukum. ${ }^{18}$

\footnotetext{
${ }^{17}$ Argumentum Per Analogiam (analogi) merupakan metode penemuan hukum dengan cara hakim mencari esensi yang lebih umum dari sebuah peristiwa hukum dan perbuatan hukum. Peristiwa dan perbuatan hukum tersebut baik yang telah diatur oleh undang-undang maupun yang belum ada peraturannya.

${ }^{18}$ Elly Erawati dan Herlien Budiono, Penjelasan Hukum Tentang Kebatalan Perjanjian, Nasional Legal Reform Program, Jakarta, 2010, HIm. 9
} 
Pasal 18 ayat (4) Undang-undang Hak Tanggungan merumuskan tentang hapusnya hak tanggungan yang dikarenakan hapusnya hak atas tanah tidak menyebabkan piutang yang dijamin menjadi hapus. Piutang kredit masih tetap ada, akan tetapi bukan lagi piutang yang dijamin secara khusus berdasarkan kedudukan istimewa kreditor. Hapusnya hak atas tanah tersebut, terjadi karena adanya overmarcht berupa bencana gempa bumi yang menyebabkan musnahnya seluruh obyek hak tanggungan yang menjadi jaminan bank, sehingga dalam hal ini debitur tidak dapat diminta pertanggungjawaban atas musnahnya obyek jaminan yang dibebankan hak tanggungan tersebut.

Apabila dihubungkan dengan kekuatan hukum sertifikat hak tanggungan yang obyeknya musnah karena bencana alam, maka berdasarkan ketentuan syarat perjanjian, yaitu obyek hak tanggungan berupa tanah yang telah musnah seluruhnya karena bencana alam, maka sertifikat hak tanggungan tersebut tidak memenuhi salah satu syarat sahnya perjanjian dalam Pasal 1320 KUH Perdata yaitu suatu hal tertentu, sehingga sertifikat hak tanggungan tersebut batal demi hukum (neitigbaarheid).

Berdasarkan pemaparan diatas maka dapat disampaikan, jika terjadi suatu peristiwa yang mengakibatkan musnahnya obyek yang diperjanjikan, maka perjanjian tersebut batal demi hukum. Perjanjian yang tidak menentukan jenis barang, jumlah, atau keadaanya adalah batal demi hukum. Jika dikaitkan dengan permasalahan musnahnya seluruh obyek hak tanggungan karena bencana alam, maka sertifikat hak tanggungan tersebut batal demi hukum. Sertifikat hak tanggungan tersebut batal demi hukum karena obyeknya seluruhnya telah musnah terkena bencana alam, sehingga tidak memenuhi salah satu syarat sahnya perjanjian yaitu suatu hal tertentu (obyek) sebagaimana yang diatur dalam Pasal 1320 KUH Perdata. Kekuatan eksekutorial sertifikat hak tanggungan yang seluruh obyeknya musnah karena bencana alam menjadi hapus, sebagaimana yang dirumuskan dalam Pasal 18 ayat (1) huruf d UndangUndang Hak Tanggungan yang merumuskan "hak tanggungan menjadi hapus karena hapusnya hak atas tanah yang dibebani hak tanggungan". Dan apabila UU Hak Tanggungan belum mengatur secara rinci mengenai kekuatan hukum sertifikat hak tanggungan apabila objeknya musnah karena bencana alam, maka berdasarkan pemaparan diatas, dapat menggunakan ketentuan di dalam UUPA dan/ atau ketentuan di dalam KUH Perdata dimana secara jelas dituliskan. Dikarenakan UU Hak Tanggungan merupakan bagian dari KUH Perdata (Lex Specialis).

\section{Perlindungan Hukum Bagi Pemegang Sertifikat Hak Tanggungan yang Objeknya Musnah Karena Bencana Alam}

Pada kasus musnahnya objek hak tanggungan, tentunya berdampak bagi kreditur sebagai pemegang hak tanggungan maupun debitur sebagai penerima hak tanggungan.untuk itu, tentunya perlu mendapatkan perlindungan hukum dari ketentuanketentuan yang ada. Melalui ini penulis ingin membahas mengenai perlindungan hukum bagi kreditur sebagai pemegang hak tanggungan.

Dalam dunia perbankan, dikenal adanya lembaga jaminan. Dimana istilah jaminan merupakan secara umum cara-cara kreditur menjamin dipenuhinya tagihan, disamping pertanggungan jawab umum debitur terhadap barang-barangnya, fungsi utamanya adalah untuk memperkecil, mengurangi resiko yang dapat dialami oleh kreditur atau bank sebagai penyalur kredit atau dengan kata lain fungsinya adalah sebagai sarana perlindungan bagi keamanan kreditur, yaitu mengenai kepastian pelunasan hutang oleh debitur atau penjamin debitur, kepastian debitur dalam melaksanakan segala kewajiban prestasinya.

Dimana objek kajian hukum jaminan dibagi menjadi 2 macam, yaitu objek materiil dan objek formal. Objek materiil hukum jaminan adalah manusia. Objek formal, yaitu sudut pandang tertentu terhadap objek materiilnya. Jadi objek formal hukum jaminan adalah bagaimana subjek hukum dapat membebankan jaminannya pada lembaga perbankan atau lembaga keuangan nonbank. Kajian hukum jaminan meliputi jaminan umum dan jaminan khusus. Jaminan khusus dibagi menjadi dua (2) macam, yaitu :

\section{Jaminan perorangan}

Hak jaminan perorangan timbul dari perjanjian jaminan antara kreditur (bank) dan pihak ketiga. Perjanjian jaminan perorangan merupakan hak relatif, yaitu hak yang hanya dapat dipertahankan terhadap orang tertentu yang terikat dalam perjanjian. ${ }^{19}$

\section{Jaminan kebendaan}

\footnotetext{
${ }^{19}$ Djuhaendah Hasan dan Salmidjas Salam,Aspek Hukum Hak Jaminan Perorangan dan Kebendaan, Jakarta,2000, HIm. 210
} 
Jaminan kebendaan merupakan hak mutlak (absolut) atas suatu benda tertentu yang menjadi objek jaminan suatu hutang, yang suatu waktu dapat diuangkan bagi pelunasan hutang debitur apabila debitur ingkar janji. Dengan mempunyai berbagai kelebihan, yaitu sifat-sifat yang dimilikinya, antara lain sifat absolut dimana setiap orang harus menghormati hak tersebut, memiliki droit de preference, droit de suite ${ }^{20}$, serta asas-asas yang terkandung padanya, seperti asas spesialitas dan publisitas telah memberikan kedudukan dan hak istimewa bagi pemegang hak tersebut/kreditur, sehingga dalam praktek lebih disukai pihak kreditur daripada jaminan perorangan. ${ }^{21}$

Menurut hukum, benda dapat dibedakan dengan berbagai cara, terdapat di dalam Pasal 503, 504, 505 KUH Perdata. Dimana dalam kasus ini, yang dijamin dengan benda tidak bergerak yaitu tanah SHM. Apabila debitur melaksanakan kewajibannya dengan baik maka peranan atau fungsi dari benda jaminan tidak akan terlihat, fungsi benda jaminan akan tampak pada saat debitur lalai atau tidak melaksanakan kewajibannya/ (wanprestasi) $)^{22}$, Baik itu di sengaja maupun tidak disengaja. Pada hasil wawancara dengan bagian "mantri"/ sales Bank BRI KCP Wirosari pada tanggal 17 Oktober 2017, menceritakan secara umum bagaimana proses pemberian kredit kepada calon debitur yang mengajukan permohonan/ pengajuan kredit, sebagai berikut;

\section{Proses Pemberian Kredit}

Proses pemberian kredit kepada debitur oleh Bank Rakyat Indonesia yang selanjutnya disebut BRI Kantor Cabang Pembantu Wirosari ${ }^{23}$ memiliki tahapan-tahapan yang harus dilalui. Dimana dimulai calon debitur mengajukan permohonan pengajuan hutang, yang disertai dengan dokumen pendukung, pemeriksaan keaslian identitas, dokumen-dokumen, dilakukan cek lapangan, kemudian diadakan analisis kredit hingga debitur dinyatakan lolos dan kreditur memberikan kucuran dana kredit. Proses ini sebagai prosedur pemberian kredit. Dalam tiap tahapannya, prosedur pemberian kredit dilakukan analisis secara

\footnotetext{
${ }^{20}$ Droit de Suite, adalah Hak kreditur untuk mengambil alih atau menjual/ melelang objek Hak Tanggungan yang dipindahtangankan kepada pihak lain selama menjadi jaminan Hak Tanggungan.

${ }^{21} \mathrm{lbid}, \mathrm{HIm} .214$

${ }^{22}$ Herawati Poesoko,Op.cit, HIm.185

${ }^{23}$ Terletak di Provinsi Jawa Tengah, Kabupaten Grobogan, Kecamatan Wirosari.
}

mendalam ${ }^{24}$ oleh "mantri"25 kemudian dianalisis oleh ADK hingga keputusan ada di tangan Kepala Unit/ Kepala Cabang Pembantu. ${ }^{26}$

Berdasarkan hasil wawancara dengan pihak Bank BRI KCP Wirosari bagian ADK, pada tanggal 23 November 2017, prosedur pemberian kredit tiap bank tidak jauh berbeda, baik bank pemerintah maupun milik swasta. Perbedaan hanya terdapat pada persyaratan-persyaratan dan penilaian/ analisaanalisa kredit yang dilakukan. Tahap yang pertama, pemohon kredit mengajukan permohonan kredit secara tertulis dalam suatu proposal. Setelah pengajuan proposal dan persyaratan terpenuhi, selanjutnya dilakukan penyelidikan berkas. Tujuan penyelidikan dokumen-dokumen yang diajukan pemohon kredit adalah untuk mengetahui apakah berkas yang diajukan sudah lengkap sesuai persyaratan yang telah ditetapkan. Jika menurut pihak perbankan belum lengkap atau belum cukup maka nasabah diminta untuk segera melengkapinya dan apabila sampai batas tertentu nasabah tidak sanggup melengkapi kekurangan tersebut, maka sebaliknya permohonan kredit dibatalkan. Dalam penyelidikan yang perlu diperhatikan adalah membuktikan kebenaran dan keaslian dari berkasberkas yang ada. ${ }^{27}$ Kemudian dilanjutkan dengan suatu penilaian kelayakan kredit.

\section{Pembuatan Akta Hak Tanggungan oleh Notaris PPAT}

Selain adanya prosedur pemberian kredit dan penilaian terhadap debitur guna usaha mengamankan dan memberikan perlindungan kreditur, adanya tahapan-tahapan dalam proses pembuatan Akta Hak Tanggungan oleh PPAT juga termasuk salah satu usaha untuk memperkecil resiko dan memberikan perlindungan kepada kreditur. Menurut Pasal 10 ayat (1) UUHT, bahwa awal dari tahap pemberian Hak Tanggungan didahului dengan janji akan memberikan Hak Tanggungan sebagai jaminan pelunasan utang tertentu, yang dituangkan didalam perjanjian utang piutang dan merupakan

\footnotetext{
${ }^{24}$ Kasmir, Manajemen Perbankan, Raja Grafindo Persada, Jakarta, HIm.95

${ }^{25}$ Sebutan pegawai BRI yang mengurusi perihal kredit ke calon debitur

${ }^{26}$ Hasil Wawancara dengan pihak Bank BRI KCP Wirosari, Kab. Grobogan dengan Bagian Sales dan ADK perihal prosedur pemberian kredit pada tanggal 17 Oktober 2017 dan 23 November 2017

${ }^{27}$ Hasil wawancara, Bank BRI KCP Wirosari, Bagian ADK, tanggal 23 November 2017
} 
bagian tak terpisahkan dari perjanjian utang piutang yang bersangkutan. ${ }^{28}$ Persiapan pembuatan APHT oleh PPAT dilakukan dengan cara mengumpulkan data yuridis yang menyangkut subjek serta data yuridis dari obyek Hak Tanggungan. Berdasarkan data yuridis yang dikumpulkan, PPAT dapat mengetahui berwenang tidaknya para pihak untuk menerima atau menolak pembuatan APHT tersebut. Pada dasarnya pemberi Hak Tanggungan wajib hadir sendiri di hadapan PPAT, namun dalam keadaan tertentu pemberi Hak Tanggungan tidak dapat hadir sendiri maka ia dapat menguasakan kepada pihak lain yang berupa Surat Kuasa Membebankan Hak Tanggungan (SKMHT). Nyatanya dilapangan yang lebih sering datang menghadap PPAT adalah kreditor saja dengan membawa surat kuasa dari debitor untuk membebankan Hak Tanggungan. Jadi dalam hal ini penghadap bertindak sebagai kuasa dari pemberi Hak Tanggungan dan sebagai penerima Hak Tanggungan. Berdasarkan hasil wawancara dengan salah satu Notaris PPAT di Kabupaten Grobogan, Moch. Farchan Ali Imron tanggal 27 Desember 2017, menurutnya SKMHT yang sudah bersertifikat harus diikuti segera dengan pembuatan APHT, dimana selambat-lambatnya 1 (satu) bulan sesudah SKMHT diberikan, atau batas waktu hingga 3 (tiga) bulan jika tanah yang dijadikan jaminan belum terdaftar atau belum bersertifikat ${ }^{29}$. Hal itu guna mencegah pembuatan APHT yang terlalu lama. Pembuatan akta harus disaksikan sekurang-kurangnya oleh 2 (dua) orang saksi. Sebelum akta ditanda tangani, PPAT wajib membacakan tentang isi akta, maksud pembuatan akta dan prosedur pendaftaran di BPN kepada para pihak. Dalam Pasal 102 ditentukan, akta PPAT dibuat sebanyak 2 (dua) lembar yang semuanya asli, satu lembar disimpan di kantor PPAT dan 1(satu) lembar lagi disimpan kepada Kepala Kantor Pertanahan untuk keperluan pendaftaran, sedangkan kepada pihak-pihak yang bersangkutan diberi salinannya. Dengan selesai dibuatnya APHT dihadapan PPAT, baru terpenuhi spesialitas, karena dalam APHT selain nama, identitas lengkap kreditor dan pemberi Hak Tanggungan (debitor), wajib disebut juga secara jelas dan piutang, nilai tanggungannya juga uraian jelas tentang benda sebagai obyek Hak Tanggungan. Kemudian timbul

\footnotetext{
${ }^{28}$ Maria Darus Zaman, Perjanjian Kredit Bank, Penerbit Alumni, Bandung, 1980, HIm. 121

${ }^{29}$ Hasil wawancara dengan Moch.Farchan Ali Imron, Notaris PPAT, di Kabupaten Grobogan, tanggal 27 Desember 2017.
}

kewajiban PPAT untuk mendaftarkan APHT tersebut ke Kantor Pertanahan untuk memenuhi syarat publisitas, karena adanya Hak Tanggungan tersebut, siapa kreditor pemegangnya, piutang dan berapa jumlahnya yang dijamin serta benda yang mana yang dijadikan jaminan, dengan mudah dapat diketahui oleh pihak-pihak berkepentingan. Berdasarkan temuan di lapangan, maka dapat disimpulkan bahwa pemberian Hak Tanggungan dilakukan di kantor PPAT dengan dibuatnya akta Pemberian Hak Tanggungan oleh Pejabat tersebut, yang bentuk dan isinya ditetapkan dengan Peraturan Menteri Negara Agraria/ Kepala BPN Nomor 3 Tahun 1996. Fomulirnya disediakan Badan Pertanahan Nasional.

\section{Perlindungan Asuransi Terhadap Objek Hak Tanggungan}

Dalam kasus musnahnya objek Hak Tanggungan, ternyata dalam melakukan wawancara terhadap Bank BRI KCP Wirosari, ada tindakan pencegahan yang dilakukan oleh pihak bank/ kreditur, selain melakukan seleksi dengan berbagai tahapan prosedur pemberian kredit hingga tahapan pembuatan akta di kantor Notaris dan atau PPAT hingga penerbitan sertifikat Hak Tanggugan oleh BPN. Pihak kreditur memiliki cara lain yaitu dengan mengusulkan objek tanah yang dibebani hak tanggungan diasuransikan dengan pihak asuransi yang bekerja sama dengan pihak kreditur. Untuk dapat memberikan hak tanggungan didahului dengan perjanjian utang piutang yang didalamnya terdapat klausula tentang pemberian hak tanggungan sebagai jaminan pelunasan hutang, dan dituangkan dalam akta yaitu Akta Pemberian Hak Tanggungan (APHT) yang dibuat oleh PPAT (Pasal 10 ayat (2) UU Hak Tanggungan). Dalam APHT wajib memenuhi Asas Spesialiteit dan Asas Publisiteit. Pada APHT juga diperkenankan mencantumkan janji-janji yaitu janji asuransi (Pasal 11 ayat (2) huruh i UUHT). sebagai pelaksanaannya, kreditor meminta agar debitor mengasuransikan obyek hak tanggungan. Untuk mengasuransikan obyek hak tanggungan, dibuatkan suatu perjanjian pertanggungan kerugian yang termuat dalam suatu akta yaitu polis.Polis tersebut secara hukum menimbulkan kewajiban bagi penjamin kepada kreditor apabila terjadi peristiwa 
yang dapat mengakibatkan musnah/rusaknya obyek hak tanggungan sebagai pelunasan utang debitor. ${ }^{30}$

Dalam APHT dapat dicantumkan janji untuk mengasuransikan obyek hak tanggungan, maka sebagai tindak lanjut diadakannya perjanjian pertanggungan kerugian. Jika terjadi musnahnya obyek hak tanggungan kreditor dapat mengajukan klaim kepada perusahaan asuransi atas nama debitor yaitu sebagai penerima kuasa dari debitor untuk menerima uang ganti rugi sebagai pelunasan utang debitor. Apabila terjadi kredit macet, obyek hak tanggungan musnah jika obyek hak tanggungan diasuransikan, kreditor dapat meminta ganti kerugian kepada penanggung dengan mengajukan klaim atas nama penerima kuasa dari debitor terhadap obyek hak tanggungan yang diasuransikan. Sedangkan bila obyek hak tanggungan tidak diasuransikan, untuk mengambil pelunasan piutang debitor maka jaminan khusus akan berubah menjadi jaminan umum yaitu tunduk pada Pasal 1131 KUHPerdata. Dalam pemberian kredit, bank selalu menggunakan prinsip kehati-hatian maka untuk menghindari risiko terjadinya kredit macet oleh debitor, bank dapat mencantumkan janji agar debitor mengasuransikan benda jaminan sebagai pelunasan utang apabila benda jaminan rusak atau musnah. ${ }^{31}$

\section{Penambahan Klausula / Janji}

Dalam hal debitur mengajukan permohonan kredit pada pihak Bank, khususnya pada Bank BRI KCP Wirosari ada tahapan dimana debitur dibacakan atau dipersilakan untuk membaca persyaratan dan kemudian apabila setuju dan mengerti, diminta untuk tanda tangan dan memberikan nama terang pada formulir Syarat Umum atau Formulir SU yang dbubuhi materai dan stempel oleh Notaris atau PPAT.

Formulir ini berisi tentang persyaratan, dan peraturan dari pihak Bank dalam proses Hak Tanggungan. Adanya formulir ini juga salah satu bentuk pencegahan dan perlindungan bagi pihak kreditur. Dengan debitur tanda tangan di atas formulir Syarat Umum yang dibubuhi materai dan stempel Notaris atau PPAT di tiap halamannya maka pihak debitur dianggap mengerti dan setuju dengan semua persyaratan dan peraturan pihak kreditur.

\footnotetext{
${ }^{30}$ http://repository.unej.ac.id/handle/123456789/1393 6 /ASPEK HUKUM JANJI MENGASURANSIKAN OBYEK HAK TANGGUNGAN DALAM AKTA PEMBERIAN HAK TANGGUNGAN (APHT)/ BALKIS SAKINA, diakses pada tanggal 30 januari 2018 jam $13.25 \mathrm{Wib}$

${ }^{31}$ Hasil wawancara, Bank BRI KCP Wirosari Cabang Grobogan, Pada Tanggal 17 Oktober 2017
}

Sehingga berdasarkan hasil wawancara perlu adanya penambahan klausula tentang musnahnya objek hak tanggungan karena bencana alam dan bagaimana prosedurnya. Sehingga apabila di dalam prakteknya terdapat kasus seperti musnahnya objek yang dibebani hak tanggungan ada perlindungan yang lebih, salah satunya, adalah solusi yang terdapat dalam formulir SU dimana debitur juga telah membaca atau dibacakan dan bersedia setuju tanpa adanya paksaan dari pihak manapun. Sehingga timbul kekuatan hukum yang cukup kuat dalam penandatanganan di atas materai dalam formulir tersebut. Dan debitur tahu, paham dan dianggap setuju terhadap kondisi-kondisi tersebut dari awal.

Dengan banyaknya tahapan yang harus dilalui untuk melakukan permohonan pengajuan kredit baik tahapan dari pihak kreditur hingga tahapan pembuatan Akta Pembebanan Hak Tanggungan di Notaris dan atau PPAT, hal ini berguna untuk menilai apakah seorang calon debitur layak untuk diberikan bantuan kredit dari pihak kreditur, kemudian dapat memperkecil resiko terjadinya kredit macet atau debitur cidera janji dalam melaksanakan kewajibannya, walaupun dalam prakteknya masih ada kasus debitur melakukan wanprestasi. Dengan melaksanakan prinsip kehati-hatian, pihak kreditur dapat meminimalisir kerugian yang ada, karena dengan melalui banyak tahapan prosedur dan debitur dinyatakan layak oleh kreditur, maka seorang debitur dianggap mampu dalam melaksanakan kewajibannya.

\section{PENUTUP}

\section{Simpulan}

Melihat hasil pembahasan dan pemaparan di atas penulis memiliki kesimpulan sebagai berikut:

1. Kekuatan hukum Sertifikat Hak Tanggungan memiliki kekuatan hukum yang tetap dan eksekutorial dan sah. mempunyai kekuatan eksekutorial yang sama dengan putusan pengadilan yang telah memiliki kekuatan hukum tetap dan berlaku sebagai pengganti grosse acte hypotheek sepanjang mengenai hak atas tanah. Apabila objek tanah yang dibebani hak tanggungan musnah oleh bencana alam maka berdampak dengan kekuatan hukum Sertifikat Hak Tanggungan. maka berdasarkan ketentuan syarat perjanjian, yaitu obyek hak tanggungan berupa tanah yang telah musnah seluruhnya karena bencana alam, maka sertifikat hak tanggungan tersebut tidak memenuhi salah satu 
syarat sahnya perjanjian dalam Pasal $1320 \mathrm{KUH}$ Perdata yaitu suatu hal tertentu, sehingga sertifikat hak tanggungan tersebut batal demi hukum (neitigbaarheid). Berdasarkan pemaparan diatas maka dapat disampaikan, jika terjadi suatu peristiwa yang mengakibatkan musnahnya obyek yang diperjanjikan, maka perjanjian tersebut batal demi hukum. Perjanjian yang tidak menentukan jenis barang, jumlah, atau keadaanya adalah batal demi hukum. Jika dikaitkan dengan permasalahan musnahnya seluruh obyek hak tanggungan karena bencana alam, maka sertifikat hak tanggungan tersebut batal demi hukum. Sertifikat hak tanggungan tersebut batal demi hukum karena obyeknya seluruhnya telah musnah terkena bencana alam, sehingga tidak memenuhi salah satu syarat sahnya perjanjian yaitu suatu hal tertentu (obyek) sebagaimana yang diatur dalam Pasal 1320 KUH Perdata.

2. Perlindungan Hukum terhadap pemegang sertifikat hak tanggungan, khususnya di Bank BRI KCP Wirosari,Kecamatan Wirosari,Kabupaten Grobogan, untuk mengamankan kredit yang dijaminkan kepada debitor telah mendapatkan perlindungan hukum yaitu droit de preference (mempunyai hak mendahulu) daripada kreditor lain, droit de suite, mudah pelaksanaan dalam lelang, obyek Hak Tanggungan lepas dari kepailitan, tidak dapat dibagi-bagi obyek Hak Tanggungan, dan pasti hari lahirnya Hak Tanggungan. Perlindungan yang lainnya, adanya prosedur pemberian kredit, dimana memiliki tahapan-tahapan yang setiap tahapan calon debitur dinilai secara mendalam untuk dinyatakan layak atau tidak untuk mendapatkan kredit dari kreditur.

\section{Saran}

Dalam penelitian dan pembahasan tesis ini yang ditulis oleh penulis, penulis sedikit memberikan saran dalam perihal kekuatan hukum sertifikat hak tanggungan dalam hal musnahnya objek hak tanggungan karena bencana alam;

1. Menambahkan klausula di dalam akta pemberian hak tanggungan maupun pada surat kuasa membebankan hak tanggungan perihal musnahnya objek hak tanggungan karena bencana alam. Sertifikat hak tanggungan dan $\mathrm{APHT}$, tidak ada klausula yang mengatur tentang kekuatan hukum sertifikat hak tanggungan yang obyeknya musnah karena bencana alam. Seharusnya terdapat suatu klausula dalam APHT dan sertifikat hak tanggungan yang mengatur tentang kekuatan hukum sertifikat hak tanggungan yang obyeknya musnah karena bencana alam adalah hapus. Selain itu juga dapat dimasukan alasan-alasan lain yang dapat menghapuskan kekuatan hukum sertifikat hak tanggungan yaitu hutang yang dijamin dengan hak tanggungan telah dilunasi oleh debitur, dilepaskannya hak tanggungan oleh pemegang hak tanggungan, dan pembersihan hak tanggungan berdasarkan penetapan oleh Ketua Pengadilan Negeri. Klausula ini diharapkan akan memberikan kepastian hukum bagi debitur dan kreditur lain yang mengalami peristiwa musnahnya seluruh obyek hak tanggungan karena bencana alam.

2. Seringkali pada debitur yang sudah memiliki rekam jejak bagus dan pihak kreditur sudah merasa mengenal atau dekat dengan debitur, pihak kreditur/ bank menaruh kepercayaan yang berlebih, sehingga dalam prosedur pemberian kredit, melewati beberapa tahapan yang dirasa tidak perlu lagi dilakukan. Menurut penulis, memang diperlukan kedekatan secara sosial antara kreditur dan debitur, tidak sebatas dalam perjanjian kredit saja antara pihak kreditur dan debitur, namun kedekatan/ rasa kekeluargaan seharusnya tidak mempengaruhi tahapantahapan dari prosedur pemberian kredit, karena dalam setiap tahapan perlu adanya penilaian yang mendalam yang dapat memberikan perlindungan bagi kreditur. Penulis juga melihat pihak Notaris PPAT juga perlu menjalin secara kekeluargaan dengan kliennya (debitur) agar mendapatkan kepercayaan penuh dari seorang klien, mengenal klien secara dekat tidak meninggalkan sikap atau etos kerja secara professional sehingga tidak mempengaruhi tahapan-tahapan dalam prosedur penerbitan akta hingga proses sertifikat hak tanggungan rampung dan diterbitkan dan tetap sesuai dengan peraturan perundang-undangan yang berlaku.

\section{DAFTAR PUSTAKA}

Muhammad, Abdulkadir, Hukum dan Penelitian Hukum, Citra Aditya Bakti, Bandung, 2004. 
Johan Nasution, Bahder, Metode Penelitian Hukum, Mandar Maju, Bandung, 2008.

Harsono, Boedi, HukumAgraria Indonesia / Sejarah Pembentukan Undang-Undang Pokok Agraria, Djambatan, Jakarta, 1997

Ibrahim, Johhny, Teori dan Metodologi Penelitian Hukum Normatif, Bayumedia Publishing, Surabaya,2011.

Hanitijo Soemitro, Ronny.Metodologi Penelitian Hukum dan Jurimetri, Ghalia Indonesia, Jakarta, 1998.

Santoso, Urip. Pendaftaran dan Peralihan Hak Atas Tanah, Edisi Pertama, Cetakan ke-1, Kencana Prenada Media Group, Jakarta, 2010.

Sutedi, Adrian, Hukum Hak Tanggungan, Sinar Grafika, Jakarta,2010

Erawati, Elly dan Herlien Budiono, Penjelasan Hukum Tentang Kebatalan Perjanjian, Nasional Legal Reform Program, Jakarta, 2010

Muljadi, Kartini dan Gunawan Widjaja, Kebendaan Pada Umumnya, Prenada Media, Jakarta, 2003

Zarqoni, Mohammad Machfudh, Hak Atas Tanah Perolehan, Asal Dan Turunannya, Serta Kaitannya Dengan Jaminan Kepastian Hukum (Legal Guarantee) Maupun Perlindungan Hak Kepemilikannya (Property Right), Prestasi Pustaka Publisher, Jakarta, 2015.
Poesoko, Herawati, Parate Executie Obyek Hak Tanggungan (Inkonsistensi, Konflik Norma dan Kesesatan Penalaran dlam UUHT) Catatan I, Laks Bang PRESS indo, Yogyakarta, 2007

Hasan, Djuhaendah dan Salmidjas Salam, Aspek Hukum Hak Jaminan Perorangandan Kebendaan, Jakarta, 2000

Kasmir, Manajemen Perbankan, Raja Grafindo Persada, Jakarta.

Zaman, Maria Darus, Perjanjian Kredit Bank, Penerbit Alumni, Bandung, 1980

\section{INTERNET}

http://repository.unej.ac.id/handle/123456789/13936 LAspek Hukum Janji Mengasuransikan Obyek Hak Tanggungan Dalam Akta Pemberian Hak

Tanggungan (Apht)/ Balkis Sakina, diakses pada tanggal 30 januari

2018 jam 13.25 Wib

\section{NARASUMBER}

Warga Lokal Desa Kunden, Kecamatan Wirosari, Kabupaten Grobogan

Moch. Farchan Ali Imron, Notaris PPAT, di Kabupaten Grobogan

Bank Rakyat Indonesia Kantor Cabang Pembantu Kecamatan Wirosari, Kabupaten Grobogan 